\title{
A search for alternatives: Hauke Brunkhorst, Donatella della Porta and Fritz W. Scharpf on the state of the European Integration
}

\author{
Interviewees \\ Fritz W. Scharpf (scharpf@mpifg.de) \\ Max-Planck-Institut für Gesellschaftsforschung, Germany \\ Donatella della Porta (donatella.dellaporta@eui.eu) \\ European University Institute, Italy \\ Hauke Brunkhorst (brunk@uni-flensburg.de) \\ Europa-Universität Flensburg, Germany \\ Interviewers \\ Monika Eigmüller (monika.eigmueller@uni-flensburg.de) \\ Europa-Universität Flensburg, Germany \\ Martin Seeliger (martin.seeliger@uni-flensburg.de) \\ Europa-Universität Flensburg, Germany
}

This interview is a conversation held by three senior researchers, who have been inquiring the process of European integration for several decades.

\begin{abstract}
"Even if Europe is entrapped, I do not believe however that there is no alternative... quite the opposite: the crisis makes the search for alternatives not only necessary, but also possible." (D. della Porta)
\end{abstract}

Monika Eigmüller, Martin Seeliger (ME, MS): In Zeiten zunehmender nationaler Protektionismen und schwindender zwischenstaatlicher Solidarität fällt die Beschäftigung mit dem politischen und gesellschaftlichen Zukunftsprojekt „EU“ zunehmend schwer. Glauben Sie, die wissenschaftliche Auseinandersetzung lohnt noch? Oder sollten wir uns anderen Themen zuwenden und das Einigungsprojekt ad acta legen?

Fritz W. Scharpf (FS): Auch unter den gegenwärtigen Bedingungen lohnt die wissenschaftliche Suche nach pragmatisch plausiblen und politisch realisierbaren Verbesserungen der europäischen Politik. Dagegen hat eine "wissenschaftliche Auseinandersetzung", die in erster Linie die Vollendung des Zukunftsprojekts anmahnt, ihren Sinn verloren. Kritisch gewendet könnte sie allerdings die Fehleinschätzungen identifizieren, die eine proeuropäische akademische und politische Linke dazu verführt haben, alle Weiterungen der ökonomischen Integration und Liberalisierung bis in die gegenwärtige Sackgasse hinein zu unterstützen. 
Dontella della Porta (DDP): More than ever.... And especially so in 2019 as we are approaching the most contested elections of the European Parliament since its very beginning. Especially, the permanent crisis of late neoliberalism has challenged existing expectations of a gradual (and relatively uncontested) increase in European integration. Not only narratives of the opposition to existing policies, politics and polity at the EU level as a sleeping giant no longer hold, but also the expectation of a constrained disagreement has been challenged by the blatant increase in EU powers to impose decisions upon the member states. As the meaning and content of European integration is put into question in the political debate, an academic reflection is all the more needed at both the normative and empirical level. Three main visions of European developments might be taken as point of reference in terms of justifications of Europe: one suggests that only a European sovereignty can bring about necessary developments towards peace and welfare; one privileges cosmopolitanism as a complex effort that implies the survival of the nation states with a European vision; the third points at the importance of constructing a socially just system. All three need to be revisited in order to understand the critical junctures in and about the Great Recession.

Hauke Brunkhorst (HB): Die Europaforschung boomt längst. Die EU ist ein hoch integrierter, föderaler Zusammenschluß, der die Souveränität der Mitgliedstaaten aufgehoben hat. Nichts zeigt das besser als der Brexit, in dem es ja wesentlich um die brachiale Behauptung der Souveränität des Vereinigten Königreichs ging. Aber es klappt nicht. Sie kommen nicht raus. Mit Gewalt („,harter Brexit“) ginge es, aber nur um den Preis einer Katastrophe für Großbritannien, nicht für die EU. Und dabei fehlt dem Land die engste Bindung an die EU, weil es nicht Mitglied der Währungsunion ist. Wenn ein Land der Eurozone rausginge oder die Zone sich ganz auflösen und zum status quo ante zurückehren würde, wäre das nicht nur eine europäische Katastrophe, sondern würde eine Weltwirtschaftskrise ungeahnten Ausmaßes auslösen. Gleichzeitig führt die jetzige, immer noch intergouvernemental (und deshalb von der nordwestliche Hegemonialmacht) dominierte Struktur der Union zu einer fast totalen Politikblockade. Wenn es dann zu einer großen Krise kommt, wie sie jetzt in Italien droht, wäre auch das eine Katastrophe, die kein Betroffener diesseits und jenseits der europäischen Grenzen wollen kann. Hier stellen sich eine Reihe von Fragen. Warum wäre die Krise eines Landes, dessen Wirtschaftskraft geringer ist als die Hessens, zur Beinahe-Katastrophe der gesamten Union geworden? Warum konnten die führenden Mächte der weitgehend informellen Eurogruppe dem griechischen Parlament die Gesetzgebung diktieren und das Land ohne Einsatz eines einzigen Panzers besetzen? Warum schafft es die Führungsmacht der Union nicht, einen Flughafen in Berlin zu bauen? - Wenn das alles kein Forschungsgegenstand von höchstem praktischem Interesse ist, was ist es dann?

ME, MS: In seinem Essay Europadämmerung sieht Ivan Kristev die Schwäche der EU darin, dass sie - gleich einem Schiff im Eismeer - nur vorwärtsfahren kann und im Fall drohender Gefahr nicht zurückschalten und den Umkehrschub einleiten kann, um den drohenden Untergang zu vermeiden. Und tatsächlich scheint die EU (und ihre Mitgliedstaaten) kaum mehr handlungsfähig zu sein. Stimmen Sie dieser Beobachtung zunehmender Handlungsunfähigkeit zu und wenn ja, was meinen Sie, wie ließe sich eine solche Handlungsblockade überhaupt aufheben?

FS: Ein treffender Vergleich! Die Erklärung liegt in der Konstitutionalisierung des europäischen Rechts und im hohen Konsensbedarf der europäischen Politik. Rückschritte der Integration können deshalb nicht durch reguläre europäische Politik, sondern allenfalls durch Exit oder Non-Compliance erreicht werden. 
DDP: There is a similar metaphor that Claus Offe has suggested: entrapped Europe. As he noted, Europe has been legitimised as guarantee for future international peace, economic prosperity cum social inclusion, promotion of democracy and rule of law, counterbalancing US international power, valuable diversity and mutual supervision, as capable of managing EU-wide problems, against the untamed Anglo-Saxon model of capitalism. The very fundamental promises upon which the European narrative tried to build legitimacy became however less and less credible with economic decline, permanent negative integration and no real democracy at the EU level. In Offe's vision, the 'trap' resides then in the impossibility of exiting - as "In addition to being built on the 'wrong' currency area and being endowed with insufficient policy capacities, there is a third flow: the Euro currency is, for all practical purposes, an irreversible arrangement" $(2015,48)$.

HB: Klar stimme ich zu! Ich habe ja die Gründe schon genannt. Wie Claus Offe sagt, hat Europas Währungsunion eine Zentralbank ohne Staat und 19 Staaten ohne Zentralbank. Die einzige Instanz, die fast gleichzeitig legislativ und exekutiv, fast ohne demokratische Legitimation und mit Höchstgeschwindigkeit und größter Wirkung entscheiden kann, ist die Zentralbank. Aber sie kann sich nur in eine Richtung vor oder zurückbewegen, die Finanzwelt mit Geld fluten oder die Schotten dicht machen. Wenn dann eine kräftige Bö von der Seite kommt, ist sie geliefert und mit ihr Eurozone, die Union, Europa und weit darüber hinaus in konzentrischen Kreisen der Rest der Welt.

ME, MS: Viele Beobachter sind sich weitgehend einig, dass spätestens mit Einführung des Euro nur noch die Wahl zwischen einer Vielzahl "mikroökonomischer", also technischer Alternativen gegeben ist, während die eigentlich politischen, makroökomischen Alternativen, die früher, links' und, rechts' markierten, gar nicht mehr als Alternativen im demokratischen Wettbewerb angeboten werden. Wie kann in Europa die verlorene demokratische Kernkompetenz, in Wahlkämpfen makroökonomische Alternativen zwischen Links und Rechts entscheiden zu können, wiedergewonnen werden?

FS: Der politische Raum lässt sich schon lange nicht mehr mit dem eindimensionalen Links/Rechts-Schema erfassen. In den achtziger Jahren gewann die Dimensionen post-industriell/industriell an Bedeutung, und heute stehen die Dimensionen egalitär/wirtschaftsliberal und kommunitaristisch/kosmopolitisch im Vordergrund der politischen Auseinandersetzung - wobei die zweite im europäischen Kontext weitgehend mit national/pro-Integration gleichgesetzt werden kann. Hinzu kommt seit Gründung der Währungsunion eine dritte, territorial-strukturelle Entgegensetzung zwischen den basalen Interessen der von binnenwirtschaftlichem Wachstum und der von export-orientiertem Wachstum abhängigen südeuropäischen und nord-ost-europäischen politischen Ökonomien. Selbst wenn es also politische Auseinandersetzungen in einem europäischen öffentlichen Raum gäbe, ließen sich die Fronten nicht mehr im Rechts-Links-Schema organisieren.

DDP: Even if Europe is entrapped, I do not believe however that there is no alternative... quite the opposite: the crisis makes the search for alternatives not only necessary, but also possible. As Antonio Gramsci suggested long ago, crises might help in challenging hegemonic thinking. Some emerging actors on the Left often refer to Gramsci's concept of an organic crisis in which new ideas, perspectives and practices emerge from the weakening of the cementing capacity of the dominant ideology and of the capability for incorporation by the ruling class. As in Gramsci's interregnum, also nowadays the old is not yet dead and 
the new not yet born, monsters can rise, but also so can opportunities for oppositional actors.

HB: Um die Demokratie zu retten, müssen wieder substanzielle Wahlmöglichkeiten im politischen Rechts-Links-Spektrum geschaffen werden, vor allem und zuerst in Europa, aber auch in den Nationalstaaten, die sie einmal hatten, aber nicht mehr haben, seit wir in einer Welt leben, in der nicht Märkte von Staaten, sondern Staaten von Märkten beherrscht werden. Ökonomisch sind wir in einer ähnlichen Situation wie Roosevelt beim Amtsantritt im Jahr 1933. Da ist Durchwursteln keine Option und der Status Quo kein Argument mehr. Damals hatten die Amerikaner die Wahl zwischen einer rechten, konservativen und einer linken, progressiven Wirtschaftspolitik, und sie haben zu ihrem Glück links gewählt. Die Linke aber in Europa nicht mehr wählbar. Auf dem Höhepunkt der griechischen Staatsschuldenkrise hat Junker das offene Geheimnis des europäischen Verfassungsrechts spät nachts in einer Hotelbar ausgeplaudert und den anwesenden Reportern von Arte erklärt, eine Regierung, so links wie Syriza, sei in Europa nicht wählbar. Der Nationalstaat kann als Demokratie nicht mehr überleben und Europas Union hat nicht die Entscheidungsmacht, das, was seine Staaten nicht mehr können, zu tun, zwischen linker und rechter Makroökonomie zu wählen. Ohne diese Macht aber gibt es nur noch „Fassadendemokratie" (Habermas).

ME, MS: In diesem Zusammenhang ist sicher auch das wiederholte Plädoyer für eine RePolitisierung der EU zu sehen: Würde jenseits öffentlichkeitsferner, weitgehend technokratischer Dauerverhandlungen entlang politischer Linien wieder gestritten und Kontroversen und Konflikte über politische Inhalte auch auf EU-Ebene öffentlich ausgetragen werden, könnten auch politische Parteien und Programme sichtbar werden und zu einer europaweit streitenden Öffentlichkeit beitragen. Was denken Sie - Ist Politisierung die Lösung?

FS: Unter den Bedingungen multi-dimensionaler Konflikte müsste Politisierung die (sehr begrenzten) Möglichkeiten konsensualen politischen Handelns und intergouvernementaler Kompromisse vollends blockieren - und so die Desintegration beschleunigen.

DDP: Claus Offe suggested that in an 'entrapped' Europe, the financial, political, social and cultural crises have contributed to disabling the agency of those very forces that might be capable of developing a European alternative. In fact, the previous expectation that integration generates the actors that are capable of producing more integration is disconfirmed by the growing discomfort with the EU. Nevertheless, a re-politicization is already happening, as research has clearly pointed at, through the increase in the topics addressed as connected to Europe, the polarization of opinions, diversity of actors. In the past, neofunctionalist approaches to the EU had assumed that adaptation between problems and levels of governance would bring about more and more integration, through a selfsustaining process. Public opinions about EU integration were considered as not- salient, based on weak preferences and not interacting with broader issues/conflicts. In the 2000s there was then the politicization of European integration through referendums and elections, as the EU was no longer insulated from domestic politics and vice-versa. Initially constrained, dissent became more and more politicized during the financial crisis, as the EU clearly failed to fulfil its promises.

HB: Ja, das denke ich. Wenn wir unsere Situation mit derjenigen der Roosevelt-Regierung von 1933 vergleichen, erscheinen Furcht und Bescheidenheit als der größtmögliche Fehler. Die Roosevelt-Regierung hatte doch überhaupt keine Ahnung, wie man die Krise würde 
lösen können. Es gab kein experimentum crucis wie später beim Neoliberalismus, den man lieber erst mal in Chile ausprobiert hat. Die Rooseveltadministration aber wußte wie jeder, der es sehen konnte und wollte, um das ungeheure Unrecht, das die Krise zur Folge hatte, und sie wußte, dass es, wollte man die Sache an der Wurzel fassen, massiver Veränderungen bedurfte. Normativ war die Perspektive klar und auch deshalb am Ende erfolgreich. Also verschärften sie die Rhetorik des Klassenkampfes, mobilisierten die Arbeiter und die Gewerkschaften und starteten eine Serie politischer Programme, um wenigstens das größte Unrecht zu beheben. Roosevelt wusste auch, dass es eine neue Weltordnung brauchte, um die soziale Demokratie zu errichten und zu stabilisieren, und dass man politisch handeln musste, um sie herbeizuführen. Auch diese Option war normativ. Es ging um die Aufhebung einer Weltordnung, in der faschistischen Staaten dabei waren, ein Land nach dem andern zu erobern und das „Unrecht wie Wasser tranken“ (Kant). Dieselbe Art von Bedrohung zeichnet sich heute in neuer Form ab, und sie ist eine Folge der postkolonialen Konstellation, in der die reichen Länder des Nordens im globalen Süden zwar (derzeit) keinen Genozid verüben oder billigend in Kauf nehmen, aber trotzdem das Unrecht wie Wasser trinken, dessen Namen Outsourcing, Landgrabbing, Darwin's Nightmare und Giftmüllverklappung sind (Lessenich, 2016).

ME, MS: Den wachsenden Schwierigkeiten auf Ebene der Systemintegration steht auf Ebene der Gesellschaften interessanter Weise eine zunehmende Sozialintegration der Union gegenüber: Trotz wachsender Protektionismen und euroskeptischer Stimmungen in einigen Teilen der europäischen Gesellschaft ist die Identifikation mit der EU gleichbleibend hoch und weisen Studien darauf hin, dass es um die Solidarität der EuropäerInnen untereinander gar nicht so schlecht bestellt ist. Könnte dies ein Hoffnungsschimmer für die Zukunft der EU sein? Können diese zarten Triebe transnationaler Gesellschaftsbildung angesichts der gravierenden institutionellen Fehlstellungen bestehen?

FS: Die geringe politische Belastbarkeit solcher Ergebnisse der Meinungsforschung würde sich zeigen, wenn es um die europäisch-solidarische Rechtfertigung von spürbaren nationalen Opfern - höheren Steuern, niedrigeren Renten oder weniger Beschäftigung in den öffentlichen und sozialen Diensten - ginge. Plausibler als die Inanspruchnahme europäischer Solidaritätsbereitschaft für Transfers zwischen den Mitgliedstaaten wäre vermutlich deren Nutzung für EU-eigene Steuern, die den sozialpolitischen Handlungsspielraum der Union erweitern könnten.

DDP: I do not think the EU can easily rely on international solidarity or identification as Europeans as a basis for legitimation. These trends could help developing cosmopolitan visions of Europe but would not support dominant EU policies of border building. To the opposite: the EU is losing support among young generations that are more oriented towards solidarity because of its cynical position of issues of migration and refugees. In our research on political participation among young people, Europe (as the EU) was not at all taken for granted. For many, Europeanism was too narrow a vision and the EU a fortress. The deals with Turkey or Libya to stop migration at the cost of supporting authoritarian regimes (and very brutal ones), the criminalization of NGOs who help saving lives in the Mediterranean sea, as well as the increasing securitization are producing negative feelings towards the EU among those with more 'cosmopolitan' and inclusive visions.

HB: Das können sie, aber nur wenn wir ernsthaft versuchen, das ganze institutionelle Rahmenwerk der Union zu verändern. Nicht alles auf einmal, aber schrittweise, und in großen Schritten in die richtige Richtung. Erst das Parlament und die Arbeitslosenversicherung, dann das Militär, wenn es denn überhaupt noch nötig ist. 
ME, MS: Wenn man nicht nur auf die Parlamente und die nationalen Öffentlichkeiten schaut, sondern auf den europaweiten Konflikt zwischen den in der Eurogruppe unter Deutschland vereinten Nordländern und den südeuropäischen Ländern in der Griechenlandkrise, zeichnet sich da nicht bereits eine neue, noch außer- und vorparlamentarische Unterscheidung von Regierung und Opposition in Europa ab?

FS: Der Nord-Ost/Süd-Konflikt in der Eurozone ist gewiss der Tat eine Dimension potenziell virulenter politischer Auseinandersetzung. Dabei geht es auch um den ideologischen Streit zwischen neoliberalen und keynesianischen Zielen und Instrumenten der Politik, der im Nationalstaat in der Tat zwischen Regierung und Opposition ausgetragen werden könnte. In der Währungsunion allerdings hat der Konflikt eine territoriale Basis in den divergenten und allenfalls gewaltsam zu verändernden sozio-ökonomischen und polit-ökonomischen Strukturen der EWU-Mitgliedstaaten. Dieser Konflikt kann nicht als demokratische Konkurrenz zwischen Regierung und Opposition um die Zustimmung einer gemeinsamen Wählerschaft ausgetragen werden. Er wird derzeit autoritär geregelt. Und falls die Währungsunion in gegenwärtiger Form erhalten werden soll, kann die autoritäre Regelung auch nicht aufgegeben werden.

DDP: The very idea of government and opposition at the EU level is complicated by the increasing power of the least transparent and electorally accountable of the EU institutions. There might be an opposition (probably more than one) inside the European Parliament. There might even be some stronger presence of the Green and the radical Left in the new EP-which might not only compensate the loss of the social-democratic party family, but also push for politics rather than compromise (the choice of the Spitzenkandidat by the European Socialists seems to me a suicidal confirmation of their perverse tendency towards allying with the Popular Party-which is, by the way, the party of Orban). But the problem is that the EU policies are made more and more by the European Central Bank or obscure bodies like the Ecofin, and they proceed by default in the logic of a negative integration in a Europe of the market aiming at further liberalization and forgetting solidarity altogether. Government and opposition are not the more consonant categories to describe these dynamics.

HB: Ja, aber es braucht eine institutionelle Form, eine parlamentarische Demokratie oder ein funktionales Äquivalent, das die wichtigsten normativen Errungenschaften der parlamentarischen Methode der Willensbildung nicht unterbietet, also 1. den Egalitarismus (die Schweizer Direktdemokratie ist Elitedemokratie), 2. die demokratische Gesetzgebung, die alle übrigen Staatsgewalten bindet und 3. die unabdingbare, auf die Gesellschaft im Ganzen zugreifende Allzuständigkeit des Gesetzgebers. Das kann sich dann ruhig über mehrere Ebenen verteilen (Föderalismus). Wenn echte Alternativen da sind und auch offen ausgetragen, breit und kontrovers diskutiert, umkämpft und zur Wahl gestellt werden, muss man sich auch um die europäische Öffentlichkeit keine Sorgen mehr machen. Man kann ihre Struktur aber durch eine einer Vergesellschaftung der kommunikativen Produktionsmittel (Massenmedien) verbessern, die nicht so blöd, repressiv und freiheitsfeindlich ist wie des zurecht untergegangenen Realsozialismus. Wenn Referenden nicht durch Geld und Macht allein bestimmt werden wie beim Brexit, sondern die öffentlichen Räume durch öffentliche Intervention deliberativ organisiert werden wie bei den Volksabstimmungen über Abtreibung und Homoehe in Irland, funktioniert sogar direkte Demokratie.

ME, MS: Wie könnte Europa so stark werden, dass es der Erpressungsmacht des Kapitals, die darin besteht, dass sich die Investoren das Land ihrer Wahl (gerade auch in Europa) 
aussuchen können, die Länder aber nicht die Investoren, wenigstens eine gleiche Macht entgegensetzen kann?

FS: Die „Erpressungsmacht des Kapitals" ist in den Mitgliedstaaten der EU höher als in anderen kapitalistischen Demokratien, und sie ist in den Mitgliedstaaten der Währungsunion noch höher als im Rest der EU. Ein Grund liegt in den harten Liberalisierungs- und Deregulierungsregeln der EU, die zum Zweck der Perfektionierung des Binnenmarktes nicht nur „nichttarifäre Handelshindernisse“ beseitigten, sondern auch die Kapitalverkehrsfreiheit, die Niederlassungsfreiheit, die Dienstleistungsfreiheit und das Beihilfeverbot so extensiv durchgesetzt haben, dass weite Bereiche der öffentlichen Infrastruktur und Daseinsvorsorge, der sozialen Dienste und der sozialen Sicherungssysteme dem Marktwettbewerb geöffnet werden mussten - was außerhalb der EU nirgendwo sonst der Fall ist. Die Investoren können sich deshalb innerhalb der EU nicht nur die Produktionsstandorte, Unternehmen, Unternehmensverfassungen und Steuersysteme ihrer Wahl aussuchen, sondern auch die bisher öffentlichen Aufgaben, deren Privatisierung ihnen profitabel erscheint. Die Währungsunion dagegen hat makroökonomischen Wahlmöglichkeiten der Mitgliedstaaten beseitigt und durch den einheitlichen europäischen Zwang zu fiskalischer Konsolidierung und angebotsseitigen Strukturreformen ersetzt. Zugleich maximiert dieses Regime die Abhängigkeit der staatlichen Politik von den Fluktuationen und Spekulationen der internationalen Kapitalmärkte. Mit anderen Worten: Die EU und die EWU sind gewiss die allerletzten Instanzen, bei denen eine demokratische Politik Schutz vor der „Erpressungsmacht des Kapitals“ suchen sollte.

DDP: I am not sure we need to think about just the EU level if we want to address (check and constrain) the power of capital. The power of capital was checked in the past within nation states. This can still be done to a certain extent. Even the local level is important in the development of policies of protection of the public versus the private: we see it on issues such as housing or transport. Privatization of water supply and other once-public services happened also at the local level and can be reversed at the local level. The socalled 'Rebel Cities' network shows the leverage that still exists for local politics. Of course, a different Europe-a Europe of the citizens-could also help constraining the power of speculators-but this would require a very deep change in the normative order the EU is built upon. Pushing for privatization, liberalization and deregulation, the EU has been until now one of the main supporters of the increased power of capitalism.

HB: Die Antwort ist 1. transnationaler Klassenkampf und 2. transnationale Bewegungen, die sich die Inklusion nicht nur aller Klassen, sondern auch Geschlechter (sexuellen Orientierungen) und Nationalitäten („colors“, „races“) auf ihre Fahne geschrieben haben. Für die Gewerkschaften ist das der einzige Weg, die Globalisierung zu überleben. Angestellte von Google haben kürzlich ein globales Walkout organisiert und ihre Solidarität mit den Beschäftigten einer globalen Hotelkette mit dem Slogan ausgedrückt: „Workers Unite!“ Das war zwar die Parole von gestern, aber sie drückte den Internationalismus von Morgen aus. Der globale Streik ist nicht mehr unmöglich, und wenn er erst mal in Europa gelingt, könnte Europa sogar noch einmal zur Avantgarde der postkolonialen Welt werden. Aber es wäre genauso gut und effektiv, wenn es in Lateinamerika oder Afrika gelänge.

ME, MS: Europa hat eine Vertragsverfassung wie die Vereinigten Staaten. Aber während das Europarecht (wie die US-Verfassung) entgegenstehendes nationales Recht bricht, lässt sich seine Verfassung nicht durch demokratische Mehrheitsentscheidungen (mit supermajority), sondern (wie ein internationaler Vertrag) nur im Staatenkonsens ändern. Was meinen Sie, könnte die europäische Misere gelöst werden, würden solche demokratischen 
Elemente in den Prozess der Verfassungs-, bzw. Vertragsänderung und -entwicklung eingeführt werden?

FS: Auch die amerikanische Verfassung ist nur sehr schwer zu verändern. Wichtiger ist deshalb der Unterschied zwischen der „schlanken“ US Verfassung und den detaillierten europäischen Verträgen, die schon deshalb eine exzessive „Konstitutionalisierung“ des EURechts zur Folge haben (Dieter Grimm). Vor allem aber hat das europäische Richterrecht mit der extensiven Interpretation der wirtschaftlichen Grundfreiheiten und des Wettbewerbsrechts eine extrem marktliberale europäische „Wirtschaftsverfassung " geschaffen, die die nationale Politik fesselt und auch die Wahlfreiheit der europäischen Politik sehr eng beschränkt.

DDP: I am skeptical about the wisdom of increasing the power of the existing European institutions. I do not see much democracy at the EU level at the moment, and I do not believe that just allowing to make decisions by supermajorities could help addressing a deep crisis of legitimacy. The risk is to give even more competencies to institutions with very limited accountability.

HB: Hier stimme ich vollkommen mit Dieter Grimm überein. Jedes allgemeine Gesetz, das in die Zuständigkeit des einfachen Gesetzgebers gehört, heute aber in transnationalen und nationalen Verfassungen (Schuldenbremse etc.) steht, muss aus der Verfassung bzw. den Verträgen raus und der einfachen Gesetzgebung unterstellt werden. Dies wäre ein wichtiger erster Schritt. Allerdings nur in Kombination mit einer demokratischen Parlamentarisierung der Eurozone.

ME, MS: Und wie könnte das umgesetzt werden? Braucht Europa doch eine neue Verfassung, oder lässt sich das auf dem Wege stillen Verfassungswandels (also ohne am Wortlaut der Verträge etwas zu ändern) erreichen?

FS: Auch in den USA hatte der Supreme Court im ersten Drittel des vorigen Jahrhunderts eine liberale und politisch restriktive Wirtschaftsverfassung richterrechtlich durchgesetzt (Ehmke, 1961). Sie wurde in der "Verfassungsrevolution“ von 1937 vom Gericht selbst korrigiert - allerdings erst, nachdem das Gericht den New Deal blockiert, Roosevelt einen Wahlkampf zu dessen Verteidigung gewonnen und dann eine Änderung der Gerichtsverfassung angedroht hatte. Eine solche Zuspitzung ist in der EU kaum zu erwarten. Und auch im prinzipiell die „Integration durch Recht“ lobpreisenden akademischen Europarecht sind nur Außenseiter bereit, das expansive Wirtschaftsverfassungsrecht des EuGH in Frage zu stellen.

HB: Einen solchen "stillen Verfassungswandel" gab es zu Zeiten des New Deal. Der bessere (und für Europa sogar der einzige) Weg besteht meiner Meinung nach in einer grundlegenden Verfassungs- bzw. Vertragsreform, die dann aber nicht mehr an den internationalrechtlichen Staatenkonsens gebunden werden darf.

ME, MS: Wenn (wie im Fall des New Deal der 1930er und die Rights Revolution der 1970er in den USA) ein solcher, massiver Verfassungswandel ohne Verfassungsänderung möglich wäre, ließe sich das noch im bisher üblichen, eher technischen Policy-Modus durchsetzen oder nur im Zuge einer echten Politisierung mit dem Risiko massiver öffentlicher Konflikte (was der EU im Falle des Gelingens auch die fehlende Input-Legitimation verschaffen würde)? 
FS: Weder die Währungsunion noch die ultra-liberale europäische Wirtschaftsverfassung könnten im „technischen Policy-Modus" geändert werden. Eine von den Süd-Ländern betriebene Politisierung des Euro-Regime erscheint nicht ausgeschlossen. Im Erfolgsfalle würde sie die Währungsunion sprengen - was Freunde des europäischen Zukunftsprojekts nicht beklagen, sondern begrüßen sollten. Eine politisierte öffentliche Debatte über die Restriktionen einer richterrechtlich oktroyierten europäischen Wirtschaftsverfassung erscheint mir ausgeschlossen. Das Richterrecht wirkt scheinbar punktuell, trifft mal diesen, mal jeden Staat, und die konkreten Fälle finden selten politische Aufmerksamkeit. Außerdem erfordert erfolgreiche Politisierung erreichbare Ziele. Hier aber wären politische Abhilfen ausgeschlossen, und ohne massive Unterstützung durch das akademische Europarecht wären auch Forderungen nach einer Selbstkorrektur der Rechtsprechung aussichtslos. Bliebe also nur die Ermutigung der Mitgliedstaaten zu passiver Resistenz oder offener Non-Compliance, was die Freunde des Zukunftsprojekts kaum erfreuen dürfte.

DDP: I do not see mass public conflict as a risk. European institutions and scholars who saw the EU as a regulatory body hoped to increase the power of the EU while keeping a benignant support for it. They tried to legitimize the EU by the outcomes, as advantaging equally all member states. But the Great Regression challenged that idea, especially but not only for those countries that were on the losing side on an international economic competition that is of course happening also within the EU. In terms of declining trust in European institutions, the drop was much sharper in the European periphery that was most hit by the crisis, but discontent spread also in other areas. The electoral earthquake also at the core of Europe, the advance of right-wing populist parties in Northern Europe, the deep loss in support by the French president (that had tried to build his support on pro-EU stances) as well as the Brexit situation are all signs of the failure of a narrative of legitimation by the output that had pretended one could give power to EU institutions without admitting its political nature.

HB: Wie schon gesagt, sehe ich keine andere Möglichkeit. Sie ist äußerst risikoreich, aber das Risiko, am Status Quo festzuhalten, ist viel größer. Es ist erschreckend, zu sehen wie Europas politisch-mediale Eliten angesichts der drohenden Existenzkrise Italiens auf Wegsehen und auf Durchzug schalten. Dasselbe bei der sogenannten Migrationskrise. Wir sagen nix. Wir geben nix. Wir tun nix. Wir heben einfach das rote Telefon nicht mehr ab, wie Steinbrück und Merkel in den ersten, alles entscheidenden Tagen der großen Weltwirtschaftskrise, die 2008 ausbrach und immer noch andauert (Tooze, 2017). Europa belügt sich selbst, ist, wie Habermas sagt, zu einem Kontinent des mauvaise foi geworden. Die trostlose Mischung aus mauvaise foi, informellen Absprachen (am Recht vorbei) und rechtlich-politischer Handlungsblockade, die das Europa der deutschen Exportindustrie bestimmt, setzt einen fatalen Prozess der Selbstradikalisierung in Gang, den Hans Mommsen am Beispiel des deutschen Faschismus analysiert hat. Der Mechanismus ist aber allgemeiner. Wenn keine klar bindenden Rechtsnormen zustande kommen, wird von denen, die vor Ort entscheiden, immer die radikalste (und ihrem dumpfsten Vorurteil entsprechende) Alternative gewählt, und so entsteht jetzt an beiden Seiten unserer Südgrenze diesseits und jenseits des Mittelmeeres eine weitgehend rechtsfreies System KZartiger Lager, und dazwischen eine riesige Todeszone auf hoher See, in der die Rettung Schiffbrüchiger faktisch verboten und für die Retter lebens- und freiheitsgefährdend geworden ist.

ME, MS: Was ist Ihre realistische Utopie für Europa? Haben Sie die (noch)? Braucht es eine solche? 
FS: Meine reale Utopie für Europa postuliert drei Prinzipien: (1) Differenzierte Integration durch Politik statt einheitliche Integration durch Recht. (2) Wenn der EU bestimmte Aufgaben politisch übertragen werden, muss sie auch in die Lage versetzt werden, diese mit eigenen Mitteln und in eigener politischer Verantwortung effektiv zu erfüllen. (3) Zu den Aufgaben der EU gehört es nicht, die Mitgliedstaaten bei der politischen Wahrnehmung ihrer eigenen Aufgaben rechtlich zu beschränken oder zu regulieren.

Ziel der Utopie wäre eine europäische Mehrebenen-Verfassung, unter der effektives und demokratisch verantwortetes politisches Handeln in der Union und in den Mitgliedstaaten ermöglicht wird.

DDP: I would not call it a realistic utopia-but I still think it is important to reflect on European alternatives. Our research has shown how difficult it became, on the Left in particular, to even talk about Europe. Comparing contemporary social movements with those at the beginning of the millennium, we note nowadays a much more critical vision of the EU: rather than a growing acceptance and legitimation, there is increased disinterest and mistrust. The discussion on Europe is also avoided as there is too high a risk of division inside the various groups, especially on issues such as the Euro. Even if the activists are not pushing for a return to the nation state, rather stressing their principled internationalism, there is more and more disenchantment with the European dream. Europe is considered as more and more authoritarian, with the European governance increasing rather than reducing its democratic deficit. From the territorial point of view, there are claims to go 'beyond Europe'. Yet, constructing 'Another Europe', a Europe of solidarity, as going beyond the nation state is considered as a necessity. As mentioned when addressing your first question, the European elections, being the most politicized ever, will require taking a position. I do not know how much chance there is to deeply transform the existing EU institutions so they can respond to expectations of reduction in social inequalities and democracy-but I think that proposals like the introduction of a tax on capital, or criteria of social protection and solidarity, or increasing forms of citizens participations need to be developed and discussed.

HB: Ich glaube nicht, dass utopische Projekte realistisch sein können. Kants Seitenhieb gegen die politischen Realisten ist immer noch zutreffend: „Denn nichts kann Schädlicheres (...) gefunden werden, als die pöbelhafte Berufung auf vorgeblich widerstreitende Erfahrung, die doch gar nicht existieren würde, wenn jene Anstalten (die Verfassungsinstitutionen - HB) zu rechter Zeit nach den Ideen getroffen würden (...).“

\section{References and recommended literature}

Offe, C. (2015). Europe entrapped. Cambridge: Polity Press.

Lessenich, S. (2016). Neben uns die Sintflut. Die Externalisierungsgesellschaft und ihr Preis. Berlin: Hanser.

Emke, H. (1961). Wirtschaft und Verfassung. Karlsruhe: C. F. Müller.

Tooze, A. (2017). Crashed: How a decade of financial crisis changed the world. London: Allen Lane. 